\section{Ukrainian Journal \\ of Educational Studies and Information Technology}

ISSN: 2521-1234 online

Ukr. J. of Educ. Stud. and Inf. Technol, 7(2), 11-19 doi: 10.32919/uesit.2019.02.02

Vol. 7, Issue 2, 2019

UDC 004.4:378

\title{
Realization of the "Transport task" simulation software using the "Drag-and-drop" technology
}

\author{
Vira Malkina, Olha Zinovieva, Andrii Mozghovenko \\ Tavriya State Agrotechnological University, \\ Melitopol, Ukraine
}

\section{ARTICLE INFO}

History:

Received: 16.05.2019

Accepted: 15.06.2019

Published online: 27.06.2019

\section{Keywords:}

information technology training

simulation software

drag-and-drop technology

transport task

(c) V. Malkina,
O. Zinovieva,
A. Mozghovenko

This work is licensed under a "CC BY 4.0" license.

\section{ABSTRACT}

The modern educational process is becoming increasingly innovative. The most important means of educational activity are computer technology learning. The development and introduction of them into the educational process is a qualitative characteristic of the computerization of education and lay the foundations for its further informatization. The article deals with the structure and content of the initial computer simulation software or the study of the "Transport task" topic, which is intended for the development of knowledge, skills and abilities of students of computer specialties in the process of studying the "Investigation of operations" discipline. The training simulation software provides multiple passage of the material at each separate stage until the correct solution is obtained. To organize the interactive learning process, the "Drag-and-drop" method is used, which, on the one hand, allows us to use more observatory visual diagrams of the problem solving algorithm, and on the other hand, concentrates the attention of students on the main stages of the algorithm and not on the implementation of bulky mathematical calculations. The simulator is designed as a local Windows application that does not require special computer resources and can be easily installed on a personal computer in an auditorium or at home. The simulator can function in two modes practice and supervision. The simulator can be used during classes and in the process of independent work.

The training simulator differs from other types of training devices by the obligatory availability of a script for verifying the actions that the student must perform in order to accomplish the task. In the process of executing actions and commands in the simulator, the verification of expected actions in the script is performed, after the result is displayed to the user. After that, in case of wrong actions, the user is given the opportunity to correct the errors. Only after correcting them, the user can go to the next stage of solving the problem. The user receives feedback and can find out about their mistakes and ability to correct them. 


\title{
Реалізація комп’ютерної навчальної програми-тренажера «Транспортна задача» з використанням технологіï Drag-and-drop
}

\author{
Малкіна Віра Михайлівна, Зінов’єва Ольга Геннадіївна, Мозговенко Андрій Андрійович
}

Таврійський державний агротехнологічний університет, м. Мелітополь, Україна

Анотація. Сучасний освітній процес все більше набуває інноваційний характер. Найважливішим засобом навчальної діяльності стають комп'ютерні технології навчання. Розробка і впровадження їх в навчальний процес $є$ якісною характеристикою комп'ютеризації освіти, що закладає основи її подальшої інформатизації. У статті розглядається структура і зміст навчальної комп’ютерної програми-тренажера для вивчення теми «Транспортна задача», яка призначена для відпрацювання знань, умінь та навичок у студентів комп’ютерних спеціальностей в процесі вивчення дисципліни «Дослідження операцій». Навчальна програма-тренажер передбачає багатократне проходження матеріалу на кожному окремому етапі, поки не буде отримано правильний розв'язок. Для організації процесу інтерактивного навчання використовується технологія «Drag-and-drop», яка, з одного боку, дозволяє використовувати більш наочні візуальні схеми алгоритму розв'язку задачі, а з іншого - концентрує увагу студента на основних етапах алгоритму, а не на виконанні громіздких математичних розрахунків.

Ключові слова: інформаційні технології навчання; програма-тренажер; технологія Drag-and-drop; транспортна задача.

\section{INTRODUCTION}

The introduction of computers into the education system has made the algorithmicprogram learning system more relevant. In our time, the educational process organized based on modern computer technology, uses educational computer applications more often. At the same time, the educational material is divided into separate parts and after that an algorithm for the study of them is created. The student is being supervised at each stage of the training. In addition, the program performs general control over the learning process, which facilitates the correction of knowledge and its mistakes. One of the varieties of training programs is a simulation software, such training tool that offers multiple material passing until the correct solution is obtained. Such approach is quite effective while studying mathematical disciplines, when the student needs to master multistage algorithms for solving a task, while performing cumbersome mathematical calculations. The training simulation software gives the opportunity to learn the educational material on different topics in the solving specific problems mode, while the controlling the correctness of the student actions at each stage. Using the "Drag-and-drop" technology helps in organizing the process of solving a task in the learning process, it gives an opportunity to concentrate the attention of students precisely on the scheme of the algorithm, and not on the implementation of the same type of mathematical calculations.

Analysis of recent research. At the current development stage of Ukraine, the professional training of future computer profile specialists, which would be able to solve complex socioeconomic, engineering, and technical problems through the development of special software, takes on the particular significance.

One of the main directions of solving the problem is to ensure a high level of professional mathematical training for future professionals. Foremost, the role of mathematical education with the use of computer technologies as the basis for assimilation of the majority of professional disciplines is intensified.

Therefore, the educational process simulation of studying mathematical disciplines with the use of computer technologies is an urgent task, because the success of its solution depends on the training of highly skilled specialists in the computer industry. 
The development and implementation of information technologies in all spheres of human activity dictates the need to find new approaches and to develop fundamentally new requirements for the quality of the training of a qualified specialist.

The work (Osadchyi, \& Osadcha, 2012) considers the scientific and methodical aspects of the application of computer programs in the study of disciplines. The works (Zabiiaka, \& Shovkoplias, Kameneva, Koval, Sysoieva, \& Sushchenko) considered and substantiated the necessity of using modern computer technologies in the study of various disciplines. In the work (Zabiiaka, \& Shovkoplias, 2010) a software product was proposed for finding the optimal value of the target function based on the use of VBA macros. In work (Atamaniuk, Shovkoplias, \& Litvinenko, 2010) the solution of optimization problems is proposed to be carried out on the basis of the Mathcad package. In the work (Cherniakova, Litvinenko, \& Shovkoplias, 2010) the main stages of the curriculum on the "Transport task" theme are analyzed and simulated.

Resulting from the use of computer technology in the study it became possible to implement an individual approach to learning, to increase the visibility of the learning process and the intensity of training.

When using computer training programs, it is possible to organize modeling and imitation of typical practical situations of professional activity, effective training and control of the acquired knowledge and skills, to make feedback, to use visual and sound forms during training.

The analysis of recent research and publications, which began the study of scientific and pedagogical efficiency of the use of computer technologies for teaching the mathematical disciplines to students of the computer profile of higher education institution has allowed to highlight the actual issues not resolved earlier, namely: the development of scientifically based computer-oriented teaching methods with further qualitative and quantitative elaboration of empirical material received, which cause the orientation of research work.
Computer education systems open a new stage in the teaching methods of mathematical disciplines. With their help, it became possible to assimilate the most cumbersome and timeconsuming algorithms for solving mathematical problems. Computer training systems make it possible for students to complete various teaching scenarios and actions that must be performed in solving mathematical problems. Such systems are easy to use and can give an opportunity to organize effective distance learning.

In the work (Malkina, Zinovieva, \& Miroshnychenko, 2018) an instrumental service was offered and allowed the development of computer training simulators from various disciplines. Using this service, a training simulator for the "Research of Operations" discipline was developed on the "Transport Task" theme.

The purpose of this article is to describe the structure and scenario of the proposed training simulator, as well as a description of its implementation for students to study the "Transport Task" subject within the framework of studying the "Research of Operations" discipline.

\section{RESEARCH RESULTS}

Among the diversity of electronic learning resources, researchers identify several groups for solving educational tasks: reference-information, demonstration-modeling, educational and controlling (Koval, Sysoieva, \& Sushchenko, 2009).

Reference-information electronic educational materials are electronic texts of educational material, hypertext teaching materials, information materials of the Internet, directories and instructions, information materials of websites, web pages and information portals, etc. (Koval, Sysoieva, \& Sushchenko, 2009).

Demonstration-modeling electronic educational materials - Imitation multimedia models used instead of dynamic posters, computer business games, etc. (Koval, Sysoieva, \& Sushchenko, 2009).

Educational and controlling electronic teaching aids, intended for the receipt and 
control of knowledge, skills and abilities of discipline. These include electronic manuals, distance learning courses, multimedia training courses, computer training programs and simulators located directly on a personal computer or on the Internet, etc. (Koval, Sysoieva, \& Sushchenko, 2009).

Electronic simulators belong to a group of educational and controlling electronic teaching aids, which are intended for the transfer of learning content and the formation of knowledge, skills and abilities (Kameneva, 2014).

In studying mathematical disciplines, students learn problems, with algorithms of iterative character. Each next step in solving the problem is based on the results of calculations of the current stage. Therefore, it is important to teach students to perform correct calculations and pay particular attention not only to the final result of the calculation, but also to the correct use of the calculation formulas themselves. To do this, the training should be arranged in such a way that it is possible to control each individual step of the algorithm for solving the problem precisely in the process of its implementation.

The feature of the proposed training simulation software - is an ability to control user actions at each stage of the task. If the actions are performed with an error, the program indicates an error and makes it possible to fix it. While the student is not performing the correct actions, the transition to the next stage is impossible. It is precisely this way, when a student must repeat each stage of the problem solving the algorithm until obtaining the correct result, which allows working out the skills of mastering the problemsolving algorithm.

The substantive part of the proposed training simulator includes exercises that will help develop the ability of students to build a mathematical model of the transport task in matrix formulation, build a basic transportation plan based on the method of south-west angle, determine the optimality of the transportation plan, calculate potentials, and building improved transportation plan on the basis of the potential method.

The simulator is designed as a local Windows application that does not require special computer resources and can be easily installed on a personal computer in an auditorium or at home. The simulator can function in two modes practice and supervision. The simulator can be used during classes and in the process of independent work.

The training program is implemented with the use of the $\mathrm{C \#}$ language. The choice of the programming tool is due to the fact that the programming language $\mathrm{C \#}$ is a family of languages with a C-like syntax. The syntax of the $\mathrm{C} \#$ language is the closest to $\mathrm{C}++$ and Java. Language has static typing, supports polymorphism, overload of operators. C\# makes it easy to detect "drag and drop" of an object into/from programs of Windows Forms. One or more of the available «Drag-and-drop» events can be used for this. An important advantage is the fact that in the «Drag-and-drop» event handler, it is possible to check whether the object is the text and if it is located in a correct spot. This approach gives an opportunity to organize the control of the correctness of the user interactively.

Fig. 1 and Fig. 2 show the structure of the program in the form of forms and sequences diagrams.

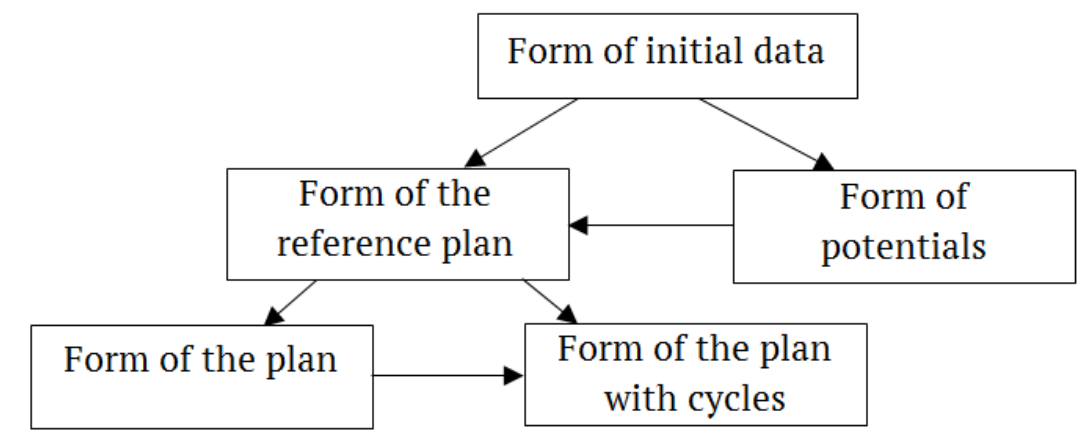

Fig. 1. - Structure of the program simulator in the form of forms chart 


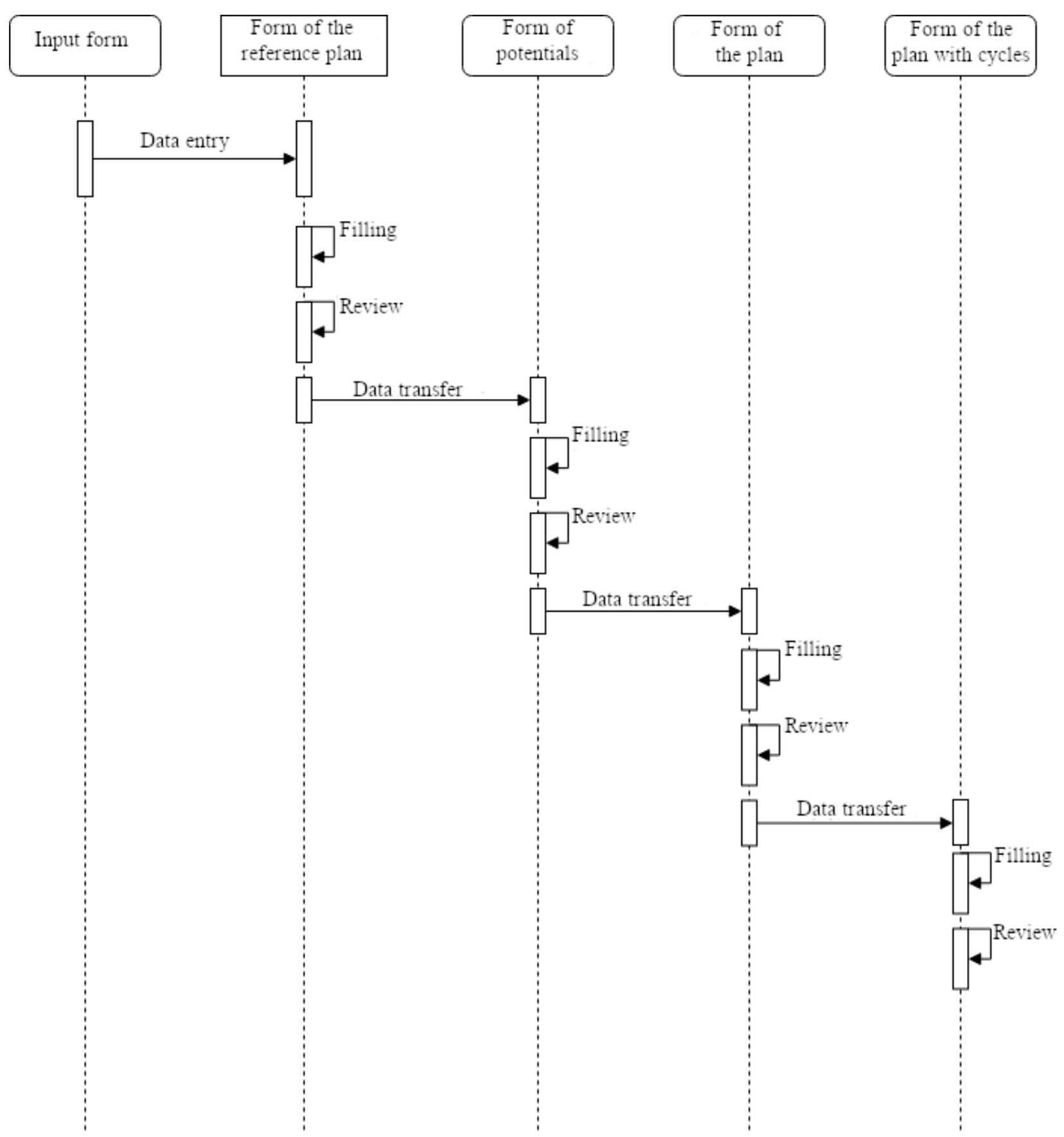

Fig. 2. - The structure of the simulation software in the form of a sequence diagram

The training simulator differs from other types of training devices by the obligatory availability of a script for checking the actions that the student must perform in order to achieve the task. In the process of executing actions and commands in the simulator, the verification of expected actions in the script is performed, after the result is displayed to the user. After that, in case of wrong actions, the user is given the opportunity to correct the errors. Only after correcting them, the user can go to the next stage of solving the problem. The user receives feedback and can find out about their mistakes and ability to correct them.

The script describes the sequence of actions that the student must perform in the process of working with the simulator.

Scenario of the work of the "Transport Task" simulation software:

Stage 1 - entering input data - the number of destinations, the number of departure points, the needs of each destination $\left(a_{i}\right)$, reserves at each departure point $\left(b_{j}\right)$, freight rates $\left(c_{i j}\right)$. The output matrix is constructed based on the output data. 
Stage 2 - construction of the basic plan by the method of the north-western angle.

Stage 3 - determining the potentials of each departure point $\alpha_{i}$ and each destination $\beta_{j}$, calculating the values $\delta_{i j}$ and verifying the optimality of the plan. If the plan is optimal a solution to the problem is obtained, if not a recalculation cycle and a new plan of transportation are being built.
Description of the implementation of the "Transport Task" simulation software.

The implementation of the first stage - the construction of the 1 transportation matrix is shown in Fig. 3. The student inputs into the cells of the table the value of the tariffs for each transport, the size of the cargo at the points of departure and the value of the need at the points of receipt of the cargo.

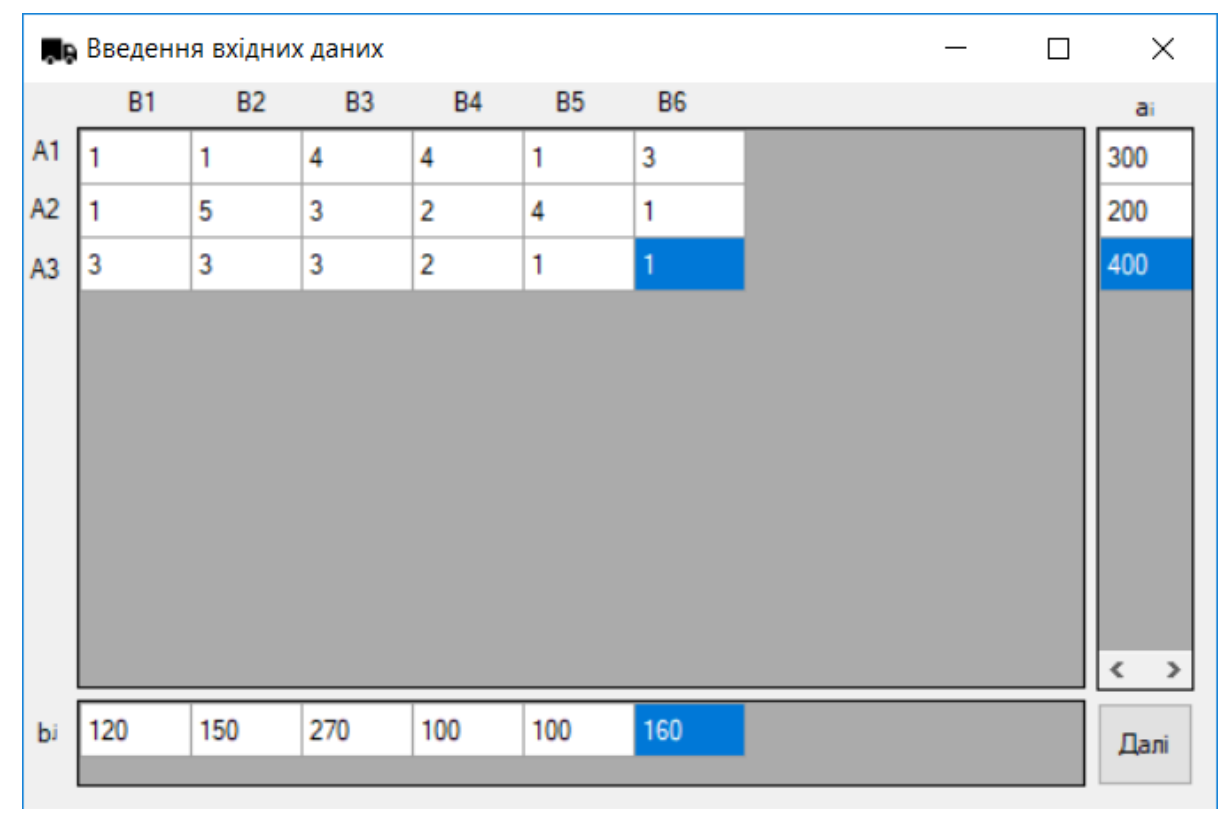

Fig. 3. - Enter the output data of the task

Fig. 4 shows the second stage the construction of the basic transportation plan by the method of the north-west angle. A student using «Drag-and-drop» technology selects the value of transportation for the appropriate cell using the supplies and needs that are located in column cells $a_{i}$ or rows $b_{j}$. After entering the value of transportation into the cell, the student recounts the value $a_{i}$ and $b_{j}$, if it is necessary. To do this, the cells in the «Recalculation of stock» and «Recalculation of needs» field are used. Recalculation by formulas is also performed with the help of «Drag-anddrop» technology. If the plan built with errors, cells in the table that have incorrectly defined transportation are highlighted in red. The student must list the false values and only then, it becomes possible to move to the next stage.

After building the basic transportation plan, we turn to the second stage of the algorithm for solving the problem. At this stage, the definition of $\alpha_{i}$ and $\beta_{j}$ potentials is made and the verification of the plan for optimality based on the calculated values $\delta_{i j}$. The calculation of potentials is performed in the form of "Potentials" using the «Drag-and-drop» technology (Fig. 5). After determining the values $\delta_{i j}$ the student must decide whether the plan is optimal. If the next iteration is necessary, use the special "Plan is optimal?" button.

At the third stage of the solution, the student builds a cycle of recalculation of the transportation plan. Determine the cell for which the conversion cycle will be constructed. For this, the student with the use of "Click" on the corresponding cell of the table and on the cells that participate in the cycle builds the loop in the form of a closed broken, as shown in the table (Fig. 6). 


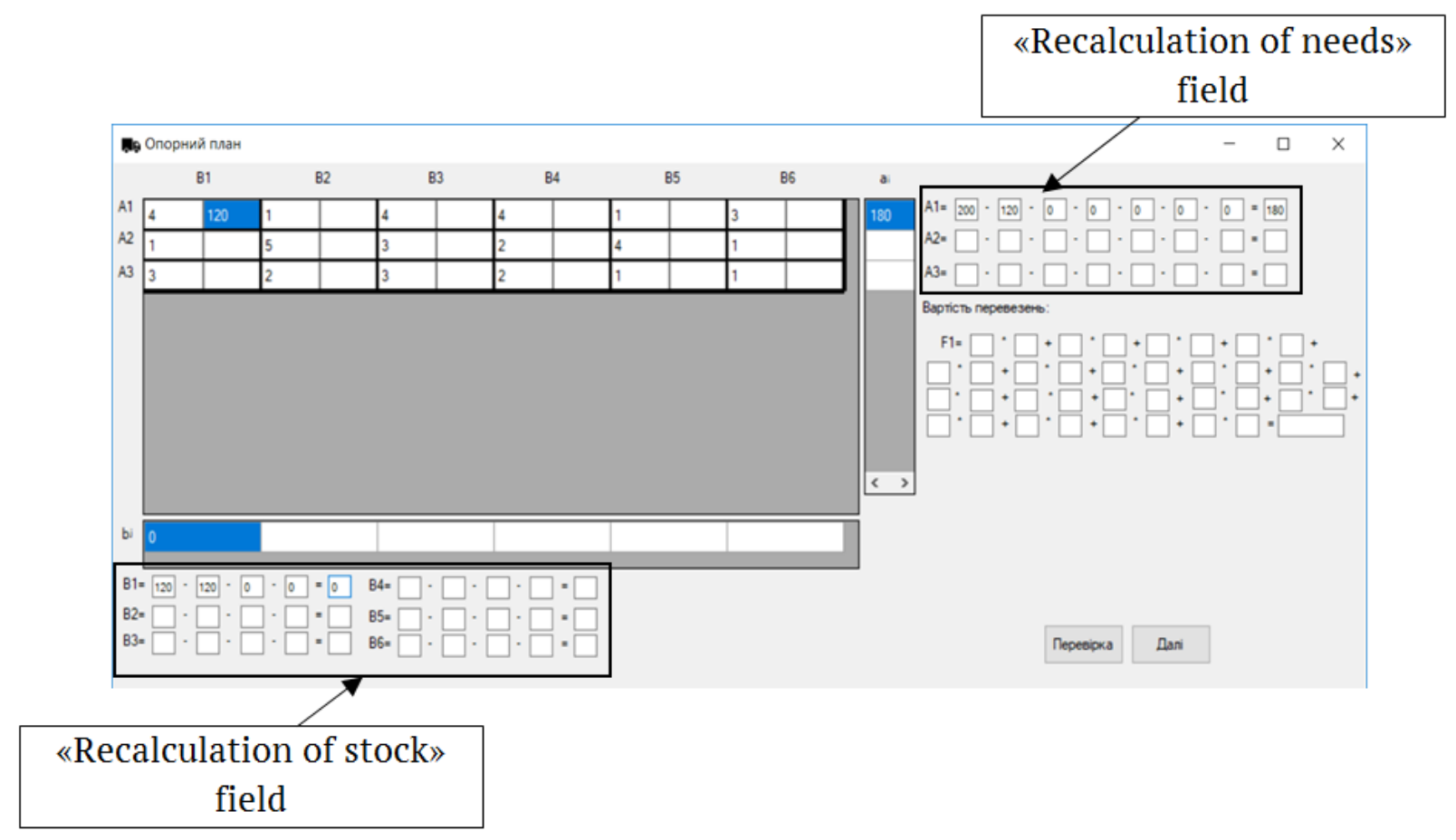

Fig. 4. - Building a basic plan and determining the cost of transportation

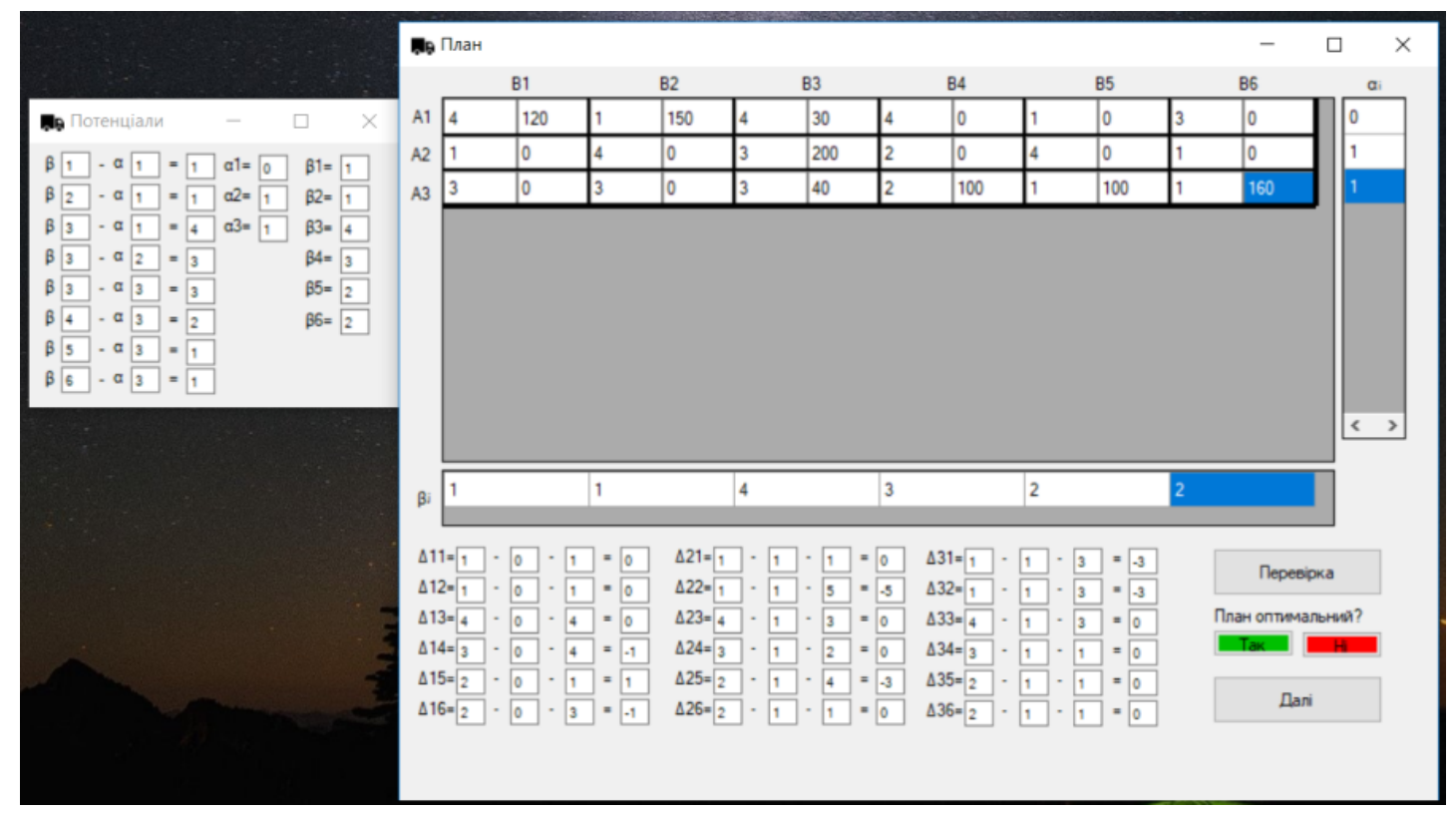

Fig. 5. - Calculation of potentials and verification of the plan's optimality

After that, in the cells that entered the recalculation cycle, the student indicates the value of the recalculation cycle.

If the calculation is not performed correctly, after clicking the "Check" button, the wrong values are highlighted in red. Then the student must list incorrect values and only after correct calculations it is possible to go to the next stage.
After carrying out the third stage and recalculating the transportation plan, it is possible to proceed to the second stage, where the potentials are calculated for the new plan and it is decided whether the plan is optimal. If the plan is not optimal then going back to the third stage is necessary. 


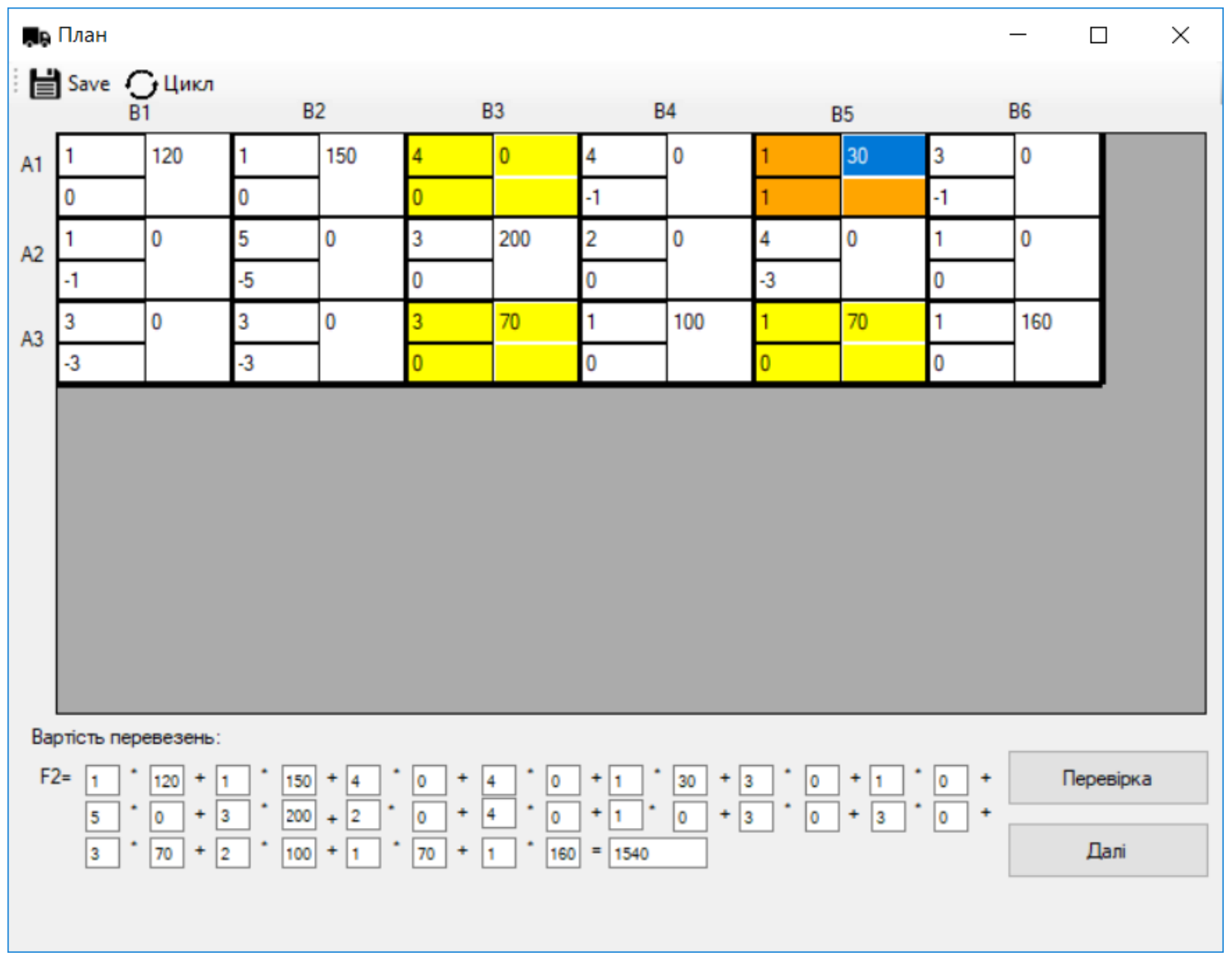

Fig. 6. - Construction of the recalculation cycle

\section{CONCLUSIONS AND PERSPECTIVES FOR FURTHER STUDIES}

The paper describes the model and work of a training simulator for studying the "Transport task" topic in the study of the "Research operations" discipline by students of the computer profile.

When creating a simulation software an interactive model with user control is used. The training simulation software provides multiple passage of the material at each separate stage until the correct solution is obtained. The proposed simulation software for the organization of the interactive learning process uses the «Drag-and-drop» technology to perform mathematical calculations at various stages of the iterative task algorithm and to control the correctness of their implementation in dialog mode. This allows us to use more observational visual diagrams of the problem solving algorithm, and concentrates the attention of students on the main stages of the algorithm, rather than on the implementation of cumbersome mathematical calculations.

Further direction of work is connected both with the development of training simulators on other topics of the "Investigation of operations" course, as well as with the implementation of new instrumental techniques and learning components - the creation of training systems, taking into account the user training experience.

\section{REFERENCES}

Atamaniuk, R. O.

Shovkoplias, O. A.,

$\&$

Litvinenko, O. A. (2010). Apply Mathcad to optimize production functions. Informatyka, matematyka, mekhanika (IMM): Materialy V Mizhvuzivskoi naukovo-tekhnichnoi konferentsii vykladachiv, spivrobitnykiv, aspirantiv i studentiv (Sumy, April 19-23 2010), 64-65. Retrieved from http://essuir.sumdu.edu.ua/handle/123456789 44187. (in Ukrainian)

Zabiiaka, A. M., \& Shovkoplias, O. A. (2010). Using VBA macros to find solutions for optimization tasks. Informatyka, matematyka, mekhanika (IMM): Materialy V Mizhvuzivskoi naukovo-tekhnichnoi konferentsii vykladachiv, spivrobitnykiv, aspirantiv 
i studentiv (Sumy, April 19-23 2010), 43-44. Retrieved from http://essuir.sumdu.edu.ua/handle/ 123456789/4028. (in Ukrainian)

Kameneva, T. N. (2014). Electronic tools for academic purposes: classification and didactic features. Kompiuter u shkoli ta simi, (8), 28-34. Retrieved from http://nbuv.gov.ua/UIRN/komp_2014_8_6. (in Russian)

Koval, T. I., $\quad$ Sysoieva, S. O., \& Sushchenko, L. V. (2009). Teachers of higher education: information technologies in pedagogical activity: educational and methodical manual. Kyiv: Vydavnychyi tsentr KNLU. (in Ukrainian)

Malkina, V. M., Zinovieva, O. H., \& Miroshnychenko, M. Yu. (2018). Software module for developing educational software using Dragand-drop technology. Ukrainian Journal of Educational Studies and Information Technology,
6 (2), 8-15. DOI: https://doi.org/10.32919/uesit. 2018.02.01. (in Ukrainian)

Osadchyi, V. V.6 \& Osadcha, K. P. (2012). Theory and practice of creating computer programs of educational purposes. Teoriia ta metodyka elektronnoho navchannia, (3), 250-255. (in Ukrainian)

Cherniakova, M. H., $\quad$ Litvinenko, O. A. \& Shovkoplias, O. A. (2010). Creation of a training program for the solution of transport problems and its application in the educational process. Informatyka, matematyka, mekhanika (IMM): Materialy V Mizhvuzivskoi naukovo-tekhnichnoi konferentsii vykladachiv, spivrobitnykiv, aspirantiv i studentiv (Sumy, April 19-23 2010), 87-88. Retrieved from http://essuir.sumdu.edu.ua/handle/ 123456789/4290. (in Ukrainian)

About the authors:

Vira Malkina, D.Sc., Professor, Professor of the Department of Computer Science, Tavriya State Agrotechnological University (18 B. Khmelnytsky Ave, Melitopol, Ukraine, 72310), ORCID: http://orcid.org/00000002-2076-2032,vmmalkina@gmail.com

Olha Zinovieva, Senior Instructor of the Department of Computer Science, Tavriya State Agrotechnological University (18 B. Khmelnytsky Ave, Melitopol, Ukraine, 72310), ORCID: https://orcid.org/0000-0003-3760-8952, olha.zinovieva@tsatu.edu.ua

Andrii Mozghovenko, Assistant of the Department of Computer Science, Tavriya State Agrotechnological University (18 B. Khmelnytsky Ave, Melitopol, Ukraine, 72310), ORCID: https://orcid.org/0000-0002-7445-8925, andrii.mozghovenko@tsatu.edu.ua

Про авторів:

Малкіна Віра Михайлівна, д.тех.н., професор, професор кафедри комп’ютерних наук, Таврійський державний агротехнологічний університет (пр. Б. Хмельницького, 18, м. Мелітополь, Україна, 72310), ORCID: http://orcid.org/0000-0002-2076-2032,vmmalkina@gmail.com

Зінов’єва Ольга Геннадіївна, старший викладач кафедри комп'ютерних наук, Таврійський державний агротехнологічний університет (пр. Б. Хмельницького, 18, м. Мелітополь, Україна, 72310), ORCID: https://orcid.org/0000-0003-3760-8952, olha.zinovieva@tsatu.edu.ua

Мозговенко Андрій Андрійович, асистент кафедри комп’ютерних наук, Таврійський державний агротехнологічний університет (пр. Б. Хмельницького, 18, м. Мелітополь, Україна, 72310), ORCID: https://orcid.org/0000-0002-7445-8925, andrii.mozghovenko@tsatu.edu.ua 